\title{
Synthesis of Chromane Derivatives via Indium-mediated Intramolecular Allenylation and Allylation to Imines ${ }^{*}$
}

\author{
Han-Young Kang ${ }^{*}$ and Yeon-Kwon Yu \\ Deparment of Chemistry and Institute for Basic Sciences, Chungbuk National Chiversity. Cheongiu. Chungbuk $361-763$. Korea \\ Received Julv 9, 2004
}

Key Words : Chromane. Indium. Intramoleçular alleny lation and ally lation reactions. Imines. Cyclizations

Indium-mediated intramolecular allylation and alleny lation to carbonyl groups have been good methods to prepare chromane structures. ${ }^{1:=}$ There are however, still some limitations in these transformations. Especially in the case of ally lation mixtures of cis and trons isomers are always produced in about $2: 1$ ratio (cis/trans). The ratio was not improved under the various reaction conditions we attempted.

Since the indium-mediated addition to carbonyl groups has been successful. ${ }^{3}$ it occurred to us that it would be worthwhile to test the addition to carbon-nitrogen double bonds. that is imine groups. We wish to report here the results of the investigations on allylation and allenylation to $\mathrm{C}=\mathrm{N}$ bond to provide the chromane structures. The whole transformations are shown below (Eq. 1 and 2).

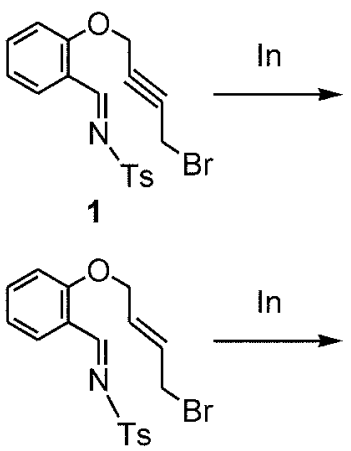

3<smiles>C=C=C1COc2ccccc2C1N</smiles>

2<smiles>C=CC1COc2ccccc2C1N</smiles>

4
Intermolecular indium-mediated Barbier type allylation to $\mathrm{C}=\mathrm{N}$ bonds could be performed in aqueous media. ${ }^{4}$ The indiuml-mediated intramolecular allenylation proceeded with ease to produce the desired allenes in various solvents including aqueous media. Two equivalents of indium and acetic acid (6 eq) as an additive were used in the same manner as the allenylation and the ally lation to $\mathrm{C}=\mathrm{O}$ bonds. ${ }^{2}$ In organic solvents such as THF, acetone, and DMF the cyclization proceeded efficiently to provide the desired product in good yields [ $75 \%(2 \mathrm{~h}) .81 \%$ (1 day), and $79 \%(2$ h), respectively]. The reaction was completed in $1-2 \mathrm{~h}$ in aqueous solvent systems such as THF/water $(1 ; 3, v / v)$ and DMF/water $(4: 1 . v / v)$ to afford the desired cyclized product in good yields ( 83 and $79 \%$ respectively). The allenylation in aqueous media presents practical advantages compared to

\footnotetext{
Dedicated to Professor Yong Hae Kinn for his outstanding achievements in organic chemistry.

'Corresponding Author. Fax: +82-43-267-2279: e-mail: hykang: $d$ ' chungbuk.ac.kr
}

the organic media. The results of the preparation of cluromane derivatives in DMF or THF/water $(1: 3, v / v)$ are summarized in Table 1. We conclude that the indiummediated intramolecular allenylation to $\mathrm{C}=\mathrm{N}$ bonds can be achieved in various solvents and is a good method to prepare cluromanes.

Next. we turned our attention to the intramolecular alylation. Under the reaction conditions similar to those reported previously ${ }^{2}$ cyclization of substrate 3 was performed. Reasonable yields were obtained in solvents such as THF acetone, ethanol. and DMF [65\% (5 h). 61\% (1 day). $54 \%(6 \mathrm{~h})$. and $53 \%(5 \mathrm{~h})$. respectively]. but acetonitrile or $\mathrm{CH}_{2} \mathrm{Cl}_{2}$ were found to be inappropriate. In aqueous THF the yield dropped to $21 \%$, and however, only a single cyclized product was observed in all of the cases of cyclization.

The results of preparing chromans by intramolecular allylation are shown in Table 2 . The results indicated that the indium-mediated allylation was not as efficient as the allenylation. About $10-20 \%$ decrease in y ields was observed. As mentioned above. in each case only a single isomer was

Table 1. Preparation of chromane derivatives by allenylation ${ }^{2}$

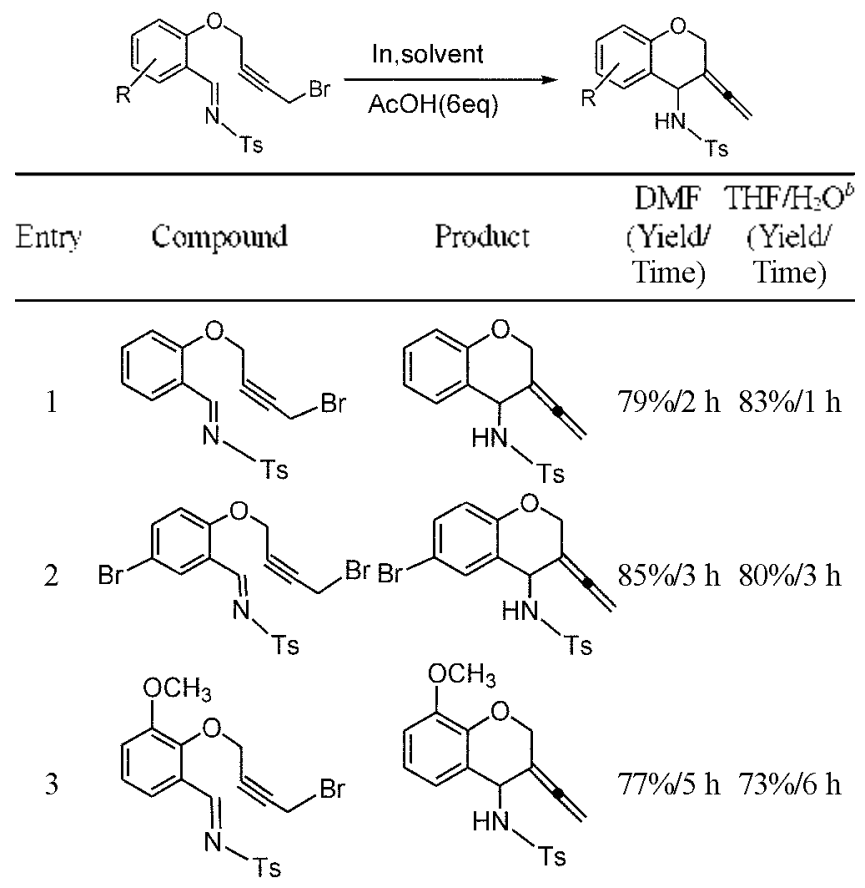

Indium (2 eq) and acetic acid (6 eq) were used. 'THF $\mathrm{H}_{2} \mathrm{O}=1: 3$ (vv) 
Table 2. Preparation of chromane derivatives by allylation ${ }^{\top}$

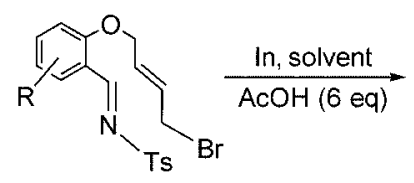

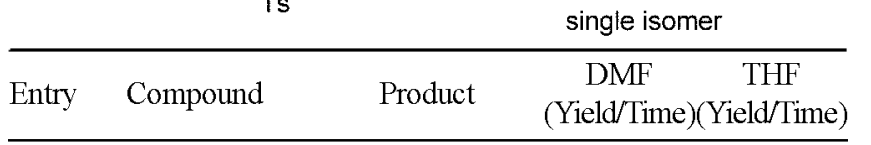

1<smiles>BrC/C=C\COc1ccccc1/C=N/[I-]</smiles><smiles>C=CC1COc2ccccc2C1NS</smiles>

$53 \% / 5 \mathrm{~h}$

$65 \% / 3 \mathrm{~h}$<smiles>S/N=C/c1cc(Br)ccc1OC/C=C/CBr</smiles><smiles>[3H]NC1c2cc(Br)ccc2OCC1C=C</smiles>

$52 \% / 6 \mathrm{~h}$

$38 \% / 3 \mathrm{~h}$<smiles></smiles><smiles>C=CC1COc2c(OC)cccc2C1N[13F]</smiles>

$55 \% / 10 \mathrm{~h} \quad 61 \% / 5 \mathrm{~h}$ observed, and the stereochemistry of the product was determined as cis by analy sis of ${ }^{1} \mathrm{H}$ NMR and NOE spectra.

Formation of the cis-product can be explained by the possible chair-like transition state $\mathbf{A}$. Considering the need of the bulky tosyl group to assume the axial geometry and possible chelation of the metal to the imino nitrogen. the chair-like transition state $\mathbf{A}$ is only possible to lead the observed cis product. Of course, the cyclization could proceed wia the synclinal transition state B. Then, it would lead to the trmas-isomer. which was not observed. It is unclear why the transition state $\mathbf{A}$ doninates over the transition state B. However, it might be appropriate to assume that in the solvent employed (DMF or THF). coordination of indium to the nitrogen atom becomes important and therefore. the chelated chair-like transition state A dominates. ${ }^{4}$

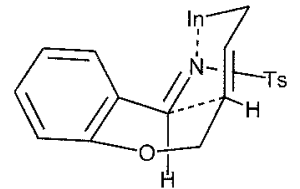

A

B

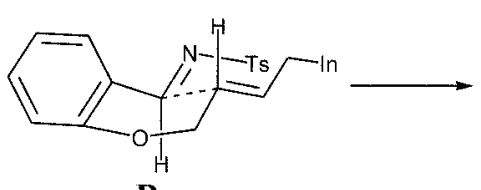<smiles>C=CC1COc2ccccc2C1N</smiles>
cis<smiles>C=C[C@@H]1COc2ccccc2C1[NH3+]</smiles>

trans
Acknowledgements. This work was accomplished with the financial support of the Center for Molecular Design and Synthesis (CMDS). KAIST and was also supported by the Brain Korea 21 project in 2003.

\section{References}

1. Kang. H.-Y.: Kiml. Y.-T.: Yu. Y.-K.: Cha. J. H.: Cho. Y. S.: Koh. H. Y. Sinlett 2004. 45

2. Cha. J. H.; Cho. Y. S.: Koh. H. Y.: Lee, E: Kim, Y.T.; Yang, H.H.; Kang. H.-Y. Bull. Korean Chem. Soc. 2004, 25, 1123.

3. (a) Shin. J. A.: Choi. K. I.: Pae. A. N.: Koh. H. Y.: Kang. H.-Y. Cho. Y. S. J. Chem. Soc. Perkin Trans. I 2001. 946. (b) Shin. J. A.: Cha. T. W.: Pae. A. N.: Choi. K. I.: Koh. H. Y.: Kang. H.-Y.: Cho. Y. S. Tetwhedron Lett. 2001. +2. 5489. (c) Bang, K.: Lee. K. Park, Y.; Lee. P. H. Bull. Korean Chent. Soc. 2002, 23, 1272. (d) Cho. Y. S.: Kang. K. H. Cha, J. H.: Choi. K. I; Pae. A. N.: Koh H. Y.: Chang. M. H. Bull Korean Chem Soc. 2002. 23. 1285. (e) Cho. Y. S.: Jun. B. K.: Kim. S.: Cha. J. H.: Pae. A. N.: Koh. H. Y.: Chang. M. H.: Hant. S.-Y. Bull. Korem Chem. Soc. 2003. 24.653.

4. (a) Chan. T. H; Lu, W. Tetrahedhon Lett 1998. 39.8605. (b) Lu. W. Chan, T. H. J. Org Chent 2000, 65.8589. (c) Lu. W. Chan. T. H. J. Org Chem $2001,66.3467$

5. Preparation of 3-vinylidene-t-(p-toluensulfonamino)chromane (2) (Table 1. entry 1). To a solution of toluenesul fonimine $1(59.0$ $\mathrm{m}$. $0.145 \mathrm{mmol}$ ) in DMF ( $2 \mathrm{~mL}$ ) was added indium powder (33.3 mg. $0.290 \mathrm{mmol}$ ) and acetic acid (52.2 $\mathrm{mg} .0 .870 \mathrm{mmol}$ ) under nitrogen atmosphere. The solution was stirred at room temperature for $2 \mathrm{~h}$ until the reaction was completed. The solution was extracted with ether $(5 \mathrm{~mL} \times 3$ ). The organic laver was washed (saturated $\mathrm{NaCl}$ ). dried $\left(\mathrm{MgSO}_{4}\right)$ and concentrated. Flash chromatography (hexane : ethyl acetate $=5: 1$ ) provided the desired product 2 as a white solid (37.4 mg. $79^{\circ}$ o). mp $137^{\circ} \mathrm{C}$ : ${ }^{1} \mathrm{H}$ $\mathrm{NMR}\left(300 \mathrm{MHz} . \mathrm{CDCl}_{3}\right) \delta 7.79$ (d. $2 \mathrm{H}, J=8.2 \mathrm{~Hz}, 2 \times \mathrm{ArH}$ in tosyl group), 7.33 (d. $2 \mathrm{H}, J=8.0 \mathrm{~Hz}, 2 \times \mathrm{ArH}$ in tosyl group). 7.19 (dd. $2 \mathrm{H} . J=7.8 .7 .7 \mathrm{~Hz} .2 \times \mathrm{ArH}$ ). 6.91 (dd. $1 \mathrm{H} . J=7.4 .7 .4 \mathrm{~Hz}$. ArH). 6.81 (d. IH. $J=8.0 \mathrm{~Hz}$. ArH). 5.0-5.1 (m. IH. NH). 4.654.9 (m. $3 \mathrm{H} . \mathrm{OCH} \mathrm{H}_{2}-\mathrm{NHCH}$ ). 4.53 (bs. $2 \mathrm{H} . \mathrm{C}=\mathrm{C}=\mathrm{CH}_{2}$ ). 2.45 (s. $\left.3 \mathrm{H} . \mathrm{ArCH}_{3}\right):{ }^{13} \mathrm{CNMR}\left(75.5 \mathrm{MHz} . \mathrm{CDCl}_{3}\right) \delta 204.3 .154 .4 .143 .6$. $137.9,129.7 .129 .6,129.1 .128 .0,127.3 .121 .3,117.2 .94 .8,79.1$. $65.4,50.3 .21 .6$

3-Vinyl-t-( $p$-toluenensulfonamino)chromane ( $\boldsymbol{t}$ ) (Table 2. entry 1). To a solution of toluenesul fonimine $3(40.0 \mathrm{mg} .0 .0980 \mathrm{mmol}$ ) in DMF ( $2 \mathrm{~mL}$ ) was added indium powder ( $22.5 \mathrm{mg} .0 .196 \mathrm{mmol}$ ) and acetic acid (35.3 $\mathrm{mg}, 0.588 \mathrm{mmol}$ ) under nitrogen atmosphere. The solution was stirred at room temperature for $5 \mathrm{~h}$ until the reaction was completed. The solution was extracted with ether $(5 \mathrm{~mL} \times 3)$. The organic layer was washed (saturated $\mathrm{NaCl}$ ). dried $\left(\mathrm{MgSO}_{4}\right)$ and concentrated. Flash chromatography (hesane : ethyl acetate $=7:$ ) provided the desired product $t$ as a white solid (17.2 me. 53\% $)$ mp 162-164 ${ }^{\circ} \mathrm{C} .{ }^{1} \mathrm{H}$ NMR $(500 \mathrm{MHz}$ $\left.\mathrm{CDCl}_{3}\right) \delta 7.82(\mathrm{~d} .2 \mathrm{H}, d=8.2 \mathrm{~Hz}, 2 \times \mathrm{ArH}$ in tosyl group), 7.35 (d. $2 \mathrm{H} . J=8.0 \mathrm{~Hz}, 2 \times \mathrm{ArH}$ in tosyl group). 7.14 (dt. lH. $J=7.8 .1 .6$ Hz. ArH). 7.07 (dd. IH. $J=7.8 .1 .4 \mathrm{~Hz} . \mathrm{ArH}$ ). 6.81 (dt. $1 \mathrm{H} . J=$ $7.1 .1 .1 \mathrm{~Hz} . \mathrm{ArH}) .6 .76$ (dd. $1 \mathrm{H} . J=8.2 .1 .0 \mathrm{~Hz}$. ArH). 5.74 (ddd. 1H. $J=17.2 .10 .3 .9 .2 \mathrm{~Hz} .-\mathrm{CH}=\mathrm{CH}_{2}$ ). 5.23 (dd. $1 \mathrm{H} . J=10.4 .1 .6$ Hz. $-\mathrm{CH}=\mathrm{C} H \mathrm{H}), 5.09(\mathrm{~d}, \mathrm{lH}, J=17.3 \mathrm{~Hz},-\mathrm{CH}=\mathrm{CH} H), 4.69(\mathrm{~m}$. 2H. NH-NHCH$), 4.21(\mathrm{dd} . J=11.2 .2 .4 \mathrm{~Hz},-\mathrm{OC} H \mathrm{HC}) .4 .10$ (dd. $1 \mathrm{H} . J=11.2,5.2 \mathrm{~Hz} .-\mathrm{OCH} H \mathrm{C}), 2.52\left(\mathrm{br}, 1 \mathrm{H}, \mathrm{CHCH}=\mathrm{CH}_{2}\right)$. 2.46 (s. $3 \mathrm{H} . \mathrm{ArCH}_{3}$ ): ${ }^{13} \mathrm{C} \mathrm{NMR}\left(75.5 \mathrm{MHz} . \mathrm{CDCl}_{3}\right) \delta 154.1$. 143.6. 138.1. 132.5. 129.8. 129.4. 129.0. 128.6. 126.8. 121.0. 120.8 .116 .6 .67 .9 .51 .1 .41 .4 .21 .6

The stereochemistry of 4 was established as cis by NOE analysis.
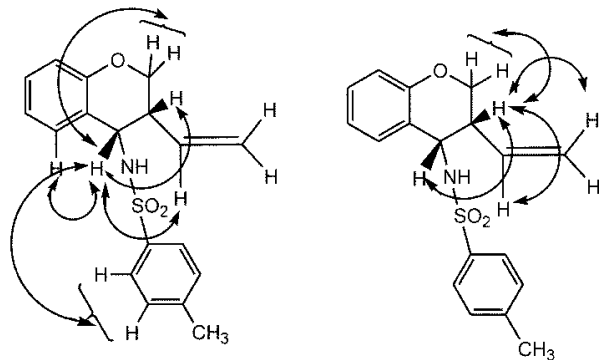